\title{
기후변화와 물 위기: \\ 재해경감을 위한 물 ODA 구상
}

\section{I. 서론}

세계적으로 급격한 인구의 증가와 가속화된 사회경제적 발전은 기후변화, 재해의 빈발, 환경파 괴, 생물다양성 감소 등의 다양한 환경 문제를 가져왔다. 특히 개발도상국의 경우 최근 빈번히 발생 하는 기후변화로 인한 자연재해의 악영향이 심각해지고 기후난민이 발생하고 있으며, 선진국의 경우 도 예외 없이 2005년 미국 허리케인 카트리나, 2011년의 동일본 대지진 및 지진해일, 2013년 서유 럽 대홍수 등 대응이 불가능한 극한규모의 재해로 엄청난 피해를 입었다.

기후변화로 대표되는 환경문제, 특히 자연재해로 인한 인적 · 경제적 피해가 속출하고 있는 현 상황에서 발전적인 접근 없이는 지속가능한 삶을 영위하기가 어려우며, 이에 따라 2012년 6월에 개 최된 리우회의에서 지속가능한 발전이 인류 공동의 달성목표라는데 합의하였다. 따라서 재해위험경 감을 개발관련 제도수립과 정책결정 등에서 포괄적으로 고려하고자 하는 움직임이 나타나고 있으며, 개발과 유관한 모든 제도와 재해위험경감 관련 제도의 면밀한 연계성 또한 강조되고 있다.

특히, 물 관련 재해의 경우, UN사무총장 물과 위생 자문위원회(UN Secretary-General's Advisory Board on Water and Sanitation, $\left.\mathrm{UNSGAB}^{1}\right)$ 의 요청으로 2007년 물과 재해 고위급 전 문가 패널(High-Level Expert Panel on Water and Disaster)이 형성되었으며 2011년 3월 발생 한 동일본 대지진과 지진해일은 본 패널의 활동을 본격화, 가속화하였다. 그간 발생한 많은 자연 재 해에 대한 사전 예방, 대응 및 사후 활동에 이르기까지 재해를 겪으며 깨닫게 된 재해관리 방안 및

1) UNSGAB(UN Secretary's Advisory Board on Water and Sanitation): 물관리, 아프리카 물문제, 물과 위생 등 지구 적 물 문제 해결을 위한 대안들을 UN 사무총장에게 자문하기 위해 설립된 기구로 주요 활동영역은 통합수자원관 리, 재정, 모니터링, 아프리카, 물과 재해 등 5 개 영역으로 분과가 나누어져 있다. 
향후 구조적/비구조적 예방 및 대응 시스템이 빨리 적용되어야 하며, 지역적·국가적으로 국제사회 의 협력을 통해 재정비되어야함이 강조되었다.

2013년 반기문 UN사무총장의 주재로 뉴욕의 UN본부에서 물 관련 재해 특별 세션이 개최되고 물과 재해 리더패널(High-level Expert and Leader's Panel on Water and Disaster, HELP)로 재구성되었으며, 올해 2015년 세계 제7차 대구경북 물포럼 개최를 통해 물 관련 재해 및 위기에 대 한 세계적 이목이 집중되었다. 특히 이번 물 포럼 개최를 계기로 한국이 리더십을 가지고 적극적으 로 물 관련 위기에 대해 해결하는 모습을 통해 한국의 국제개발협력 담당기관인 KOICA의 역할이 중 요해 질 것으로 보인다.

따라서 본 고에서 세계적인 물 위기에 대한 논의와 이러한 재해위험경감을 위한 개발활동에 적극 적인 노력을 기울이는 한국의 공적개발원조(Official Development Assistance, ODA) ${ }^{2)}$ 현황을 분 석하고 $\mathrm{KOICA}$ 의 대표적인 물관련 $\mathrm{ODA}$ 사례를 소개하며, 향후 기후변화적응과 재해경감을 위한 물 $\mathrm{ODA}$ 미래를 구상하고자 한다.

키워드: 기후변화, 재해위험경감, 개발협력, 물 ODA

\section{II. 기후변화와 물 위기}

\section{1. 기후변화와 관련된 재해 현황}

오늘날의 세계는 다양한 물 문제로 인해 인간의 생존과 경제 활동이 위협을 받고 있다. 지구촌 곳 곳에서 물 부족현상을 겪고 있으며 많은 지역에서의 물 압박은 더 나아가 이로 인한 국제적인 분쟁까 지 발생하고 있는 실정으로, 물 문제에 대한 적절한 대응은 세계의 안정과 번영에 반드시 필요한 상 황이 되었다.

지난 2014년 4월, 세계은행 김용 총재는 영국의 일간지〈가디언〉과의 인터뷰에서 향후 5년에서 10 년 안에 기후변화의 가장 중요하고 직접적인 영향으로 ‘물과 식량을 둘러싼 분쟁이 발생할 것’ 이

2) 공적개발원조(ODA): 정부를 비롯한 공공기관이 개발도상국의 경제발전과 사회복지 증진을 목표로 제공하는 원 조를 의미하며, 개발도상국 정부 및 지역, 또는 국제기구에 제공되는 자금이나 기술협력을 포함하는 개념으 로 정의할 수 있다. 이와 같은 ODA의 정의는 경제협력개발기구 개발원조위원회(OECD DAC: Organization for Economic Cooperation and Development, Development Assistance Committee)가 1961년 출범한 이후 통일되어 사용되고 있다. 
라고 언급한 바가 있다(Elliot, 2014 $4^{1)}$.

이는 전 세계의 기상이변과 지구온난화로 인한 피해가 확산되면서 기후변화에 의한 물 부족과 물 재난이 21 세기의 가장 큰 위협이라는 인식을 같이 하는 것이며, 기후변화로 인한 물 위기(홍수, 태 풍, 가뭄 등)를 해결하고 그 피해를 저감하기 위해 우리 모두가 함께 뜻을 모아 대응하는 것이 전 세 계의 안보와도 직결된 매우 중요하고도 위급한 문제라고 할 수 있다.

제I장

\section{제II장}

〈기후변화관련 재해 건수, 1980-2011〉

\section{Number of Climate-related Disasters Around the World (1980-2011)}

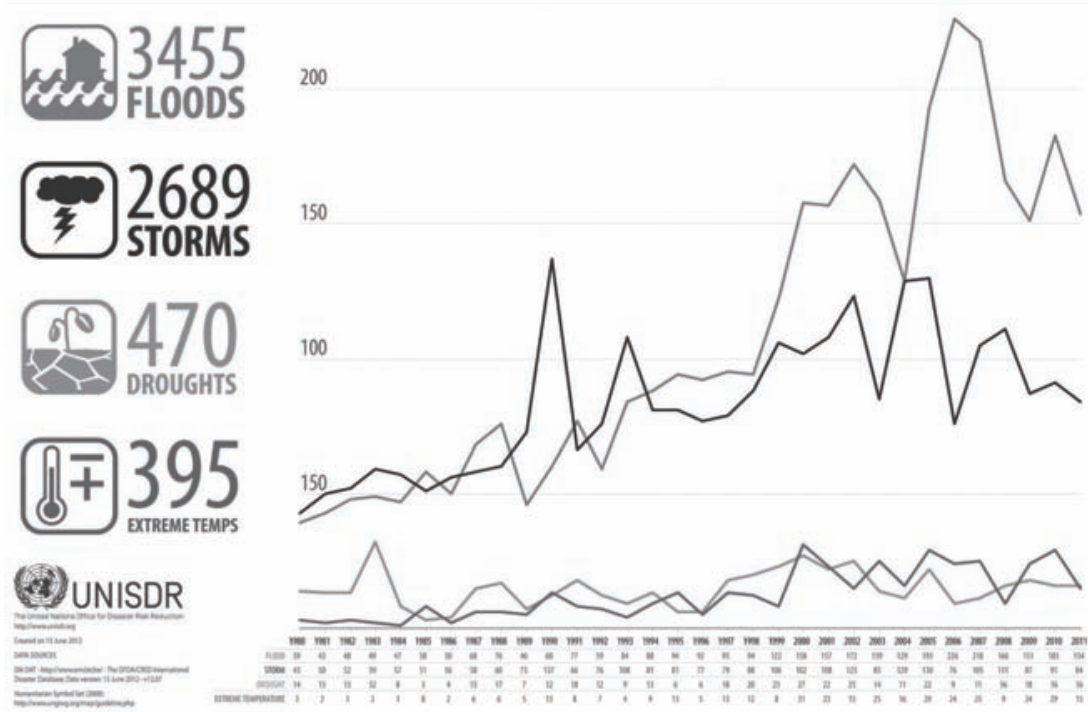

* 출처: http://www.preventionweb.net/english/professional/statistics/

IPCC는 물 부족이 특히 중부와 남부 유럽에서 증가할 것으로 예측하고 있으며, 2070년까지 이에 의해 영향을 받는 사람들의 수가 2,800 만에서 4,400 만으로 증가할 것으로 전망했다(Alcamo et al., 2007. 또한 지구 평균 온도가 $2^{\circ} \mathrm{C}$ 상승하는데 재해대응 비용은 2020 년부터 2050년까지 연간 7 백 억 달러에서 1 천억 달러가 들 것이며, 이 금액은 대부분 물 공급과 홍수관리에 필요한 물과 관련된 비용이라고 언급하고 있다(World Bank, 2010).

기후변화에도 불구하고 물이 전 지구적으로 풍부하게 고르게 분포된다면 크게 문제가 되지 않는 다(이현, 2015). 하지만, 많은 나라들이 계속해서 물 부족을 겪고 있으며 물에 대한 재난으로 생명과 재산을 잃고 있다. 
여기서 중요한 점은, 지구상에 있는 물의 총량은 지구가 생성되는 시점부터 지금까지 사실상 크게 변하지 않았다는 것이다. 하지만 세계인구는 1950년 이후 기하급수적으로 증가했고 인구의 물 소비 량 또한 지난 40 년 동안 3 배 이상 늘어났다. 이는 결국 물의 절대량을 얼마나 효율적으로 관리하고 배분할 수 있는 능력이 있는가라는 문제로 귀결된다.

\section{2. 공유하천과 물 분쟁}

이집트, 메소포타미아, 인더스, 황하 등 세계 4대 문명 발상지들의 공통점은 큰 강을 끼고 있다는 것이다. 이렇듯 인간문명의 발상은 하천으로부터 기인했으며 물로 시작된 부의 축척과 재분배는 식 량안보 및 인간생존에도 위협을 가할 만큼 중요한 요소임이 분명하다.

물은 정치적인 경계로 구분지어질 수 없다. 전 세계는 276 개의 국제 공유하천 유역이 있으며(아 프리카지역 64개, 아시아지역 60개, 유럽지역 68개, 북아메리카 46개, 남아메리카 38개), 이 중 185 개 하천유역은 $2 \sim 3$ 개의 나라에 걸쳐 흐르고 있다. 또한, 256 개 유역은 4 개 나라에(92.7\%), 20 개의 유역은 5 개 이상의 나라에(7.2\%)걸쳐 흐르며, Danube강 같은 경우에는 최대 18 개의 나라가 같은 하천유역을 공유하며 흐르고 있다. 이렇듯 지구의 $46 \%$ 가 국제공유하천 유역으로 덮여있는 것 이다(UN water, 2013).

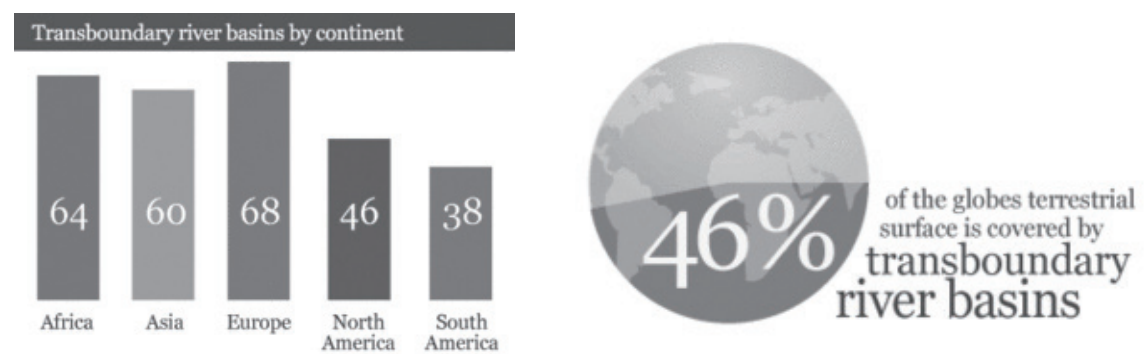

* 출처: http://www.unwater.org/water-cooperation-2013/water-cooperation/facts-and-figures/en/

대부분의 경우 물과 관련된 분쟁이나 갈등은 정치, 경제, 사회, 환경 등 다양한 요소에서 원인을 찾을 수 있다(Gehrig and Rogers, 2009). 하지만 결국 분쟁의 원인은 물 수요는 증대됨에 비하여 물 공급량은 턱없이 부족해진다는 데에서 기인하며, 특히 국제 공유하천을 둘러싼 나라들의 물을 확 보하기 위한 경쟁은 치열해지고 있는 실정이다. 
현재 진행되고 있는 대표적인 분쟁사례로는 아랄해를 둘러싼 중앙아시아 국가들, 나일강을 둘러 싼 아프리카 국가들, 그리고 티그리스강과 요르단 강을 둘러싼 중동지역의 분쟁을 예로 들 수 있다. 또한, 중국의 경제적 부상과 맞물려 중국에서 발원해 미얀마, 라오스, 태국, 캄보디아, 베트남을 거 쳐 흐르는 메콩강 유역은 항시 분쟁가능성이 높은 지역으로 국제사회의 관심이 집중되고 있다.

특히 사막지대의 나라들인 중동, 아프리카 국가들은 물이 관개용으로 가장 많이 사용되고 있기 때 문에 이러한 물 분쟁은 앞으로 더욱 가속화 될 것이다. 사막의 녹화라는 지역적인 이유로 이용 가능 한 물을 너무 많이 끌어 썼기 때문에 물 부족이 더욱 심각해지고 있으며 식량 확보와 맞물려 더 빠른 속도로 사용량은 증가하고 있어 어쩌면 다음 중동전의 원인은 '물' 이 될지도 모른다.

\section{제II장}

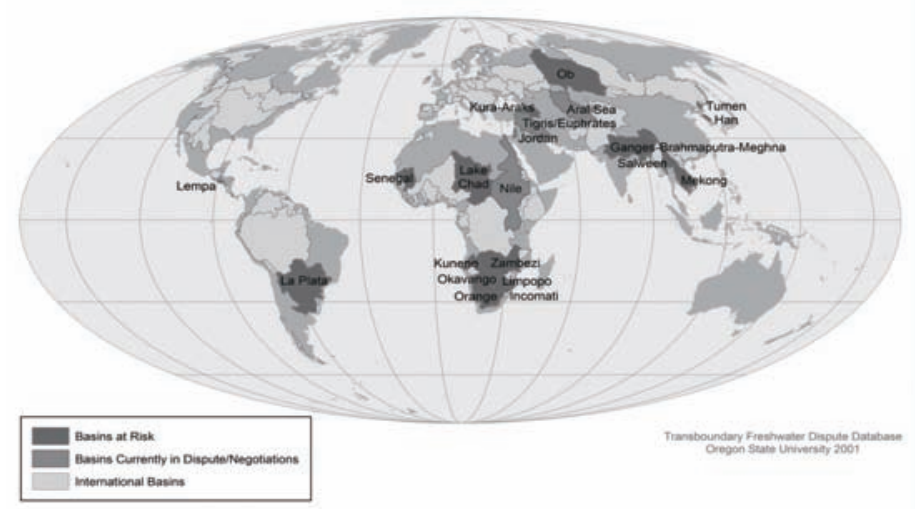

* 출처: http://www.transboundarywaters.orst.edu.

\section{3. 개발도상국의 물 부족}

물 부족과 물 재난의 문제는 특히 개발도상국에 집중되어 있다. 기후변화에 따른 홍수와 가뭄 문 제, 물 거버넌스 부재에 따른 물 분배와 확보 문제는 적절한 시설 투자 및 인력양성을 통해서 문제를 어느 정도 완화시킬 수 있으나, 이런 조치들을 실행에 옮기기 위해서는 상당한 비용이 필요하기 때 문에 개발도상국들로써는 근본적이 대책마련이 어려운 실정이다.

개발도상국의 성장요인으로 원조와 도시화의 역할은 매우 중요하다고 볼 수 있다. UN에 따르면 세계인구가 현재 약 70 억 명에서 2050년에는 90억 명에 이를 것이며, 특히 도시인구는 현재의 35억 명 수준에서 2050년에 60 억 명이 넘을 것으로 예상된다. 새로 증가하는 도시인구의 대부분인 약 30 억 명은 개발도상국의 도시에 집중될 것이며 도시화율도 현재 $49 \%$ 에서 $70 \%$ 정도로 증가할 것으로 
예상하고 있다(UN, 2007).

인구증가로 인한 도시화의 진행, 도시화로 인한 개발도상국의 경제성장은 이들 간에 서로 강한 영 향을 주고 있음을 밝히는 연구들이 발표되고 있다. 또한 도시화가 진행됨에 따라 물 사용랑이 급속 하게 증가하고 있음을 아래의 그래프에서 확인 할 수 있다.

\section{〈전 세계 부문별 물 사용량〉}

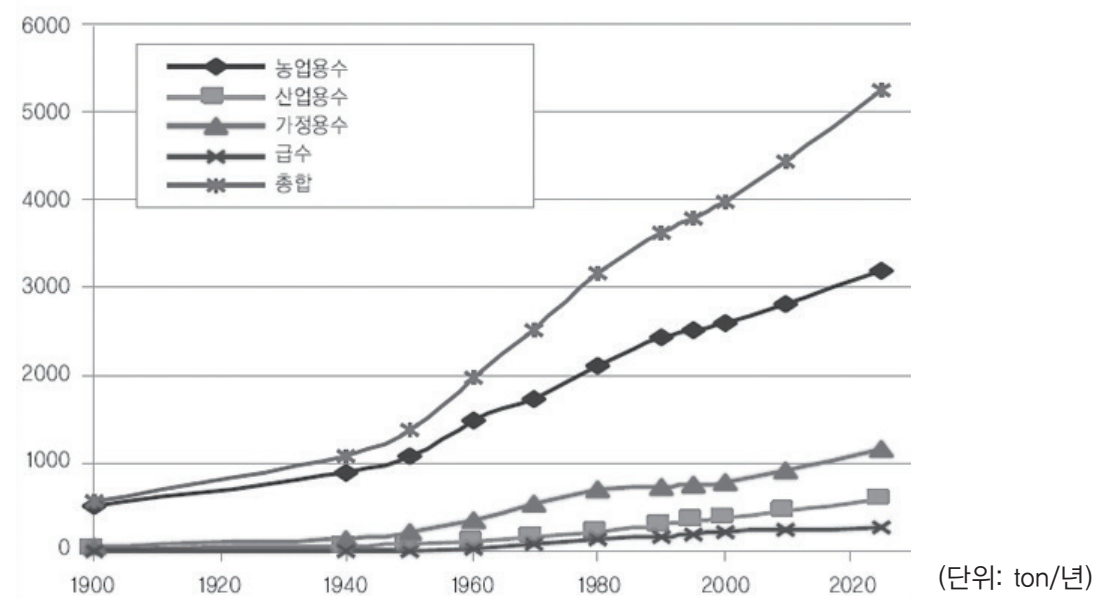

* 출처: 세계 물 미래 시나리오(2013), http://www.waterjournal.co.kr/news/articleView.html?idxno=16261

식량안보와 더불어 물 안보가 대두되고 있는 지금, 개발도상국에 안전하고도 안정적인 물을 확보 하는 것이 최우선시 되고 있으며 많은 원조기관들은 2015년에 마무리되는 새천년개발목표(MDGs) 의 안전한 식수접근률 향상과 2014년 7월에 국제적 합의가 완료된 지속가능발전목표(SDGs)를 통 해 인류가 공동으로 추구해야 할 17 개 목표를 제시하고, 그 중 '모든 사람이 이용가능하며 지속 가능 한 사용량의 식수와 위생보장(Ensure availability and sustainable management of water and sanitation for all)'의 달성을 위해 국제사회의 지원과 협력은 필수적이라고 할 수 있다.

\section{III. 재해경감을 위한 물 ODA}

\section{1. 한국의 기여와 $\mathrm{KOICA}$ 의 물분야 ODA}

전쟁의 폐허 위에 한강의 기적을 일으킨 우리나라는 공적개발원조(ODA) 수혜국에서 공여국이 된 
〈지속가능한 발전 목표: 17단계 도전 상관관계〉
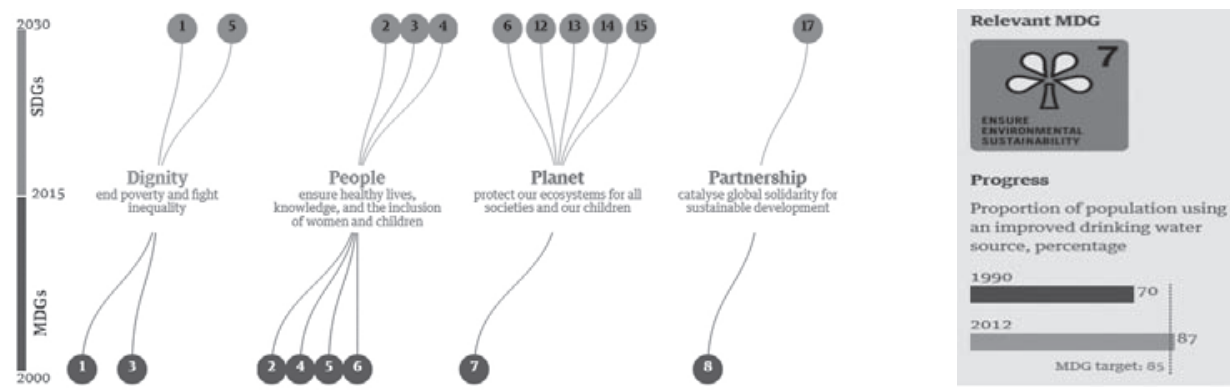

제I장

제II장

* 출처: http://www.theguardian.com/global-development/ng-interactive/2015/jan/19/sustainable-development-goalschanging-world-17-steps-interactive

〈전 세계 물 분야 지원 동향〉

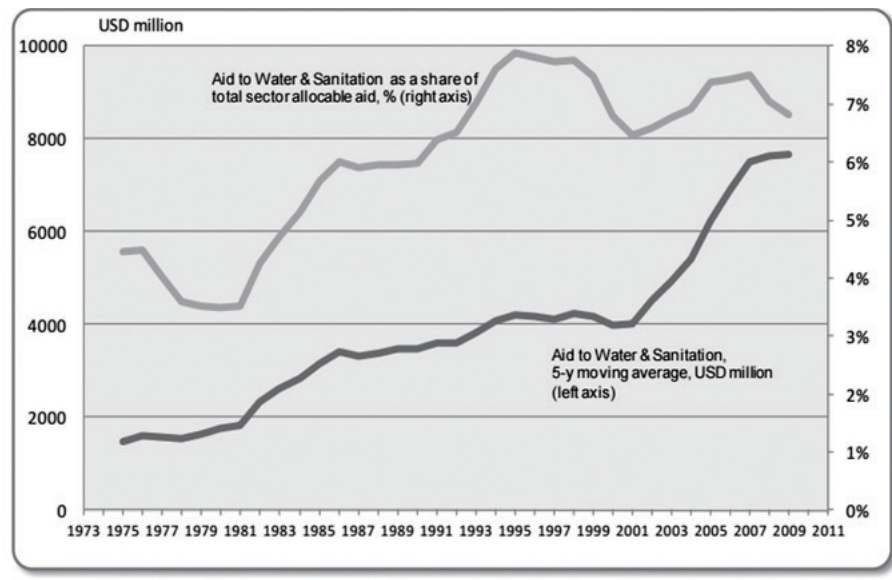

* 출처: June 2013, OECD-DAC, www.oecd.org/dac/stats/water

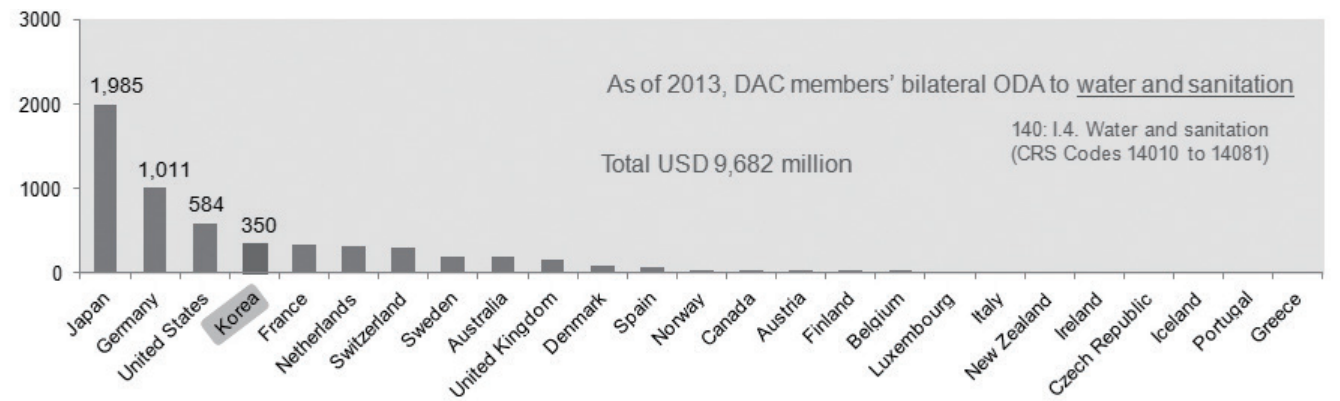

* 출처: June 2013, OECD-DAC, www.oecd.org/dac/stats/water, 
유일한 국가로서 국제적 문제 해결에 많은 관심과 적극적인 실천 의지를 갖고 행동에 옮기고 있 다. $\mathrm{OECD} / \mathrm{DAC}$ 통계에 의하면 전 세계의 물과 위생분야 지원액은 꾸준히 증가하는 추세이며, 한국 은 $\mathrm{OECD} / \mathrm{DAC}$ 가입국 중 4번째 순위로 지원하고 있다(OECD, 2013).

1991년 4월 1일에 설립된 KOICA는 'Happiness for All with global KOICA'라는 비전을 가지 고 여러 분야에서 개도국 지원사업을 진행해왔으며, 특히 전 세계적인 물 문제 해결에 대응하기 위해 $\mathrm{NGO}$ 단체와의 협력을 통한 마을단위의 식수개발 사업에서부터 식량안보와 직결된 농업용수 및 관개 수로 개발 사업, 재난예방을 위한 마스터플랜 사업 및 대규모 상하수도 건설 사업까지 다양한 규모 와 방식으로 지원을 하고 있다.

$\mathrm{KOICA}$ 의 물 분야 지원은 꾸준히 증가하는 추세이며 1991년부터 2014년까지 총 35개 국가에 약 106 개의 프로젝트 사업을 통해 총 2억 2천만 달러 추산의 사업비를 지원하였으며, 지역적으로는 90 년대 남미, 아프리카, 중동지역 지원위주에서 2000년 후반부터는 아시아지역에 중점 지원하는 추 세이다. 물 분야의 지원 사업분야 또한 상수공급 개발 및 시설개선 뿐만 아니라 소수력발전, 통합수 자원관리, 수질오염처리, 재해방지 등 다각화되고 있으며 이는 개도국의 지리적 특수성 및 국가발전 도, 지역별 특수 상황을 반영한 결과라고 할 수 있다.

\section{〈KOICA의 물 분야 ODA 사업〉}

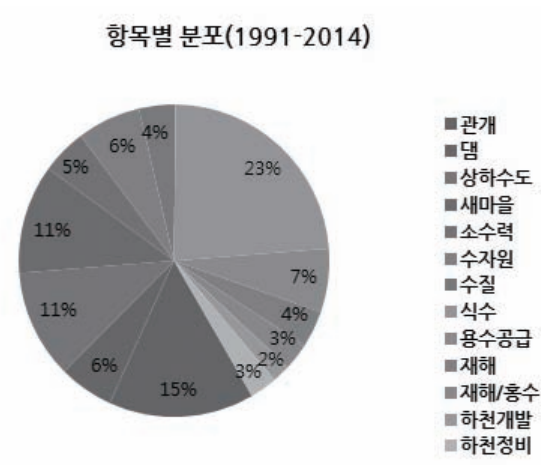

지역별 분포(1991-2014)

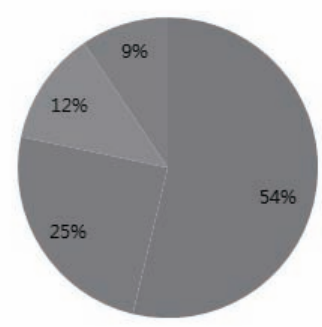

마아시아

마아프리카

푸ㅇㅜㅜㅁㅁㅣ

중동CIS

* 출처: KOICA 통계(2014)

또한, 최근 원조규모가 증가함에 따라 대규모 단위의 메가 프로젝트 실현을 위해 개발전략의 우선 수위를 고려한 개발도상국의 마스터플랜 및 사업타당성 분석을 실시하고 $\mathrm{EDCF}$ 및 GCF, GGGI 등 
다자금융기관에서의 재정 지원 가능한 자금을 연계하여 프로젝트를 진행하려고 노력하고 있다.

\section{KOICA의 경험사례: 물관리 랜드마크 사업}

$\mathrm{KOICA}$ 는 지난 2009년, 다국적 컨설팅회사 맥킨지사와 함께 우리나라가 기후변화 대응에서 리더

십을 발휘할 수 있는 36 개 분야를 집중 검토하고 이를 통해 물 관리, 저탄소에너지, 저탄소도시, 산 림과 바이오매스, 폐기물처리를 5 대 중점분야로 선정하고 이 중 '물 관리'를 최우선 중점분야로 선정 하여 동아시아기후파트너십 $(\mathrm{EACP})^{3)}$ 을 진행하였다.

\section{〈동아시아기후파트너십의 주요 분야〉}

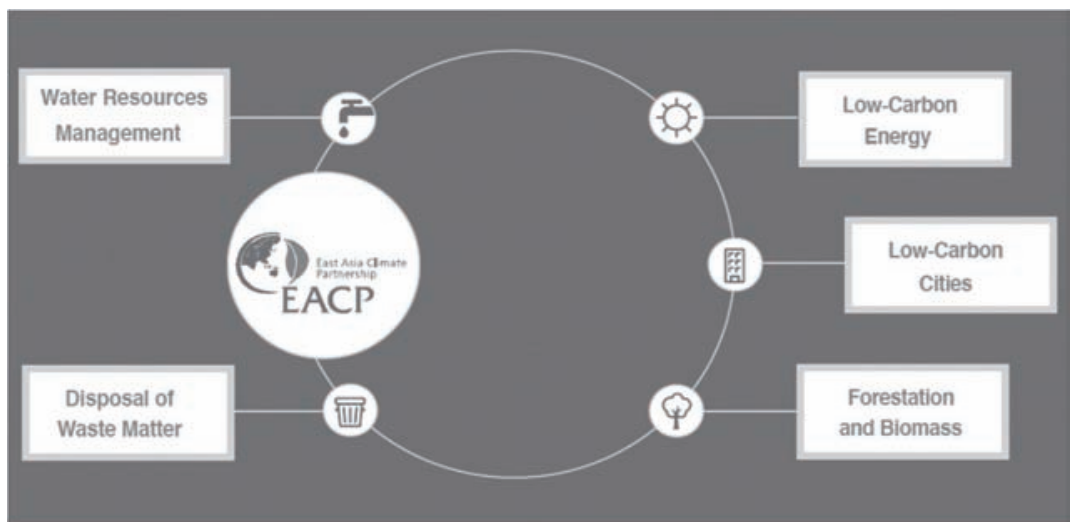

* 출처: 동아시아기후파트너십(EACP) 성과보고서

급격한 산업화와 에너지 수요 증가로 아시아의 개발도상국은 세계에서 기후변화로 인해 가장 큰 피해를 입고 있는 지역이다. 이에 따라 동 파트너십 프로그램에서는 기후변화 대응역량을 강화하고 지속가능한 개발을 도모할 수 있도록 아시아 지역을 선정하였다.

3) 동아시아기후파트너십(EACP: East Asia Climate Partnership): 개발도상국의 기후변화 대응과 아시아의 지속가능 한 성장을 위한 대한민국의 국제개발협력 사업이다. 2008년부터 총 5년간 약 2 억달러의 자금을 공적개발원조 형태로 지원했다. 
〈EACP 아시아 지역의 물 관리 사업 현황〉

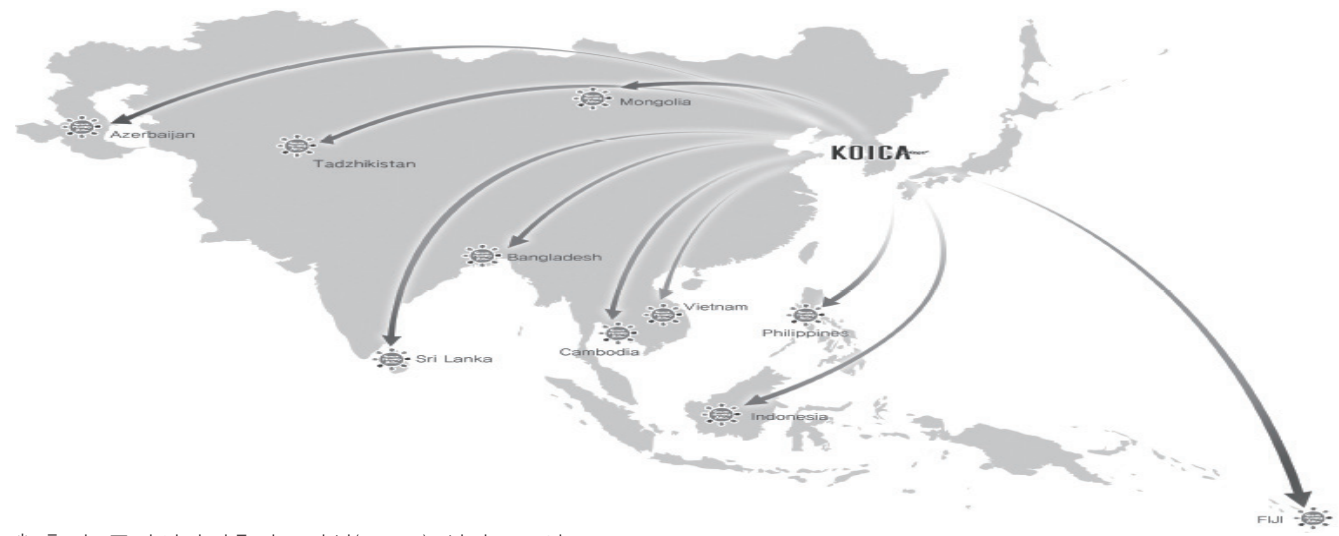

* 출처: 동아시아기후파트너십(EACP) 성과보고서

특히, 물 관리 랜드마크 사업은 사업 효과성이 높은 지역을 선정하여 물 문제에 대한 종합 솔루션 을 제공함으로써 물 관리 분야의 대표적인 사업, 즉 랜드마크형으로 수행하는 사업이다. 사업대상국 가로 각각 동북아시아, 동남아시아, 중앙아시아 지역을 대표하는 몽골, 필리핀, 아제르바이잔 3 국을 선정하였으며 2015년까지 총 6,780억 달러에 이르는 대규모 지원을 제공하였다. 이는 우리나라 무 상원조 역사상 단일규모 사업으로 가장 큰 규모이며 각 나라의 물 문제 특성을 반영한 맞춤형 종합 솔루션 지원으로 나라별로 물 문제 해결을 위한 물 산업의 기반을 마련하였다.

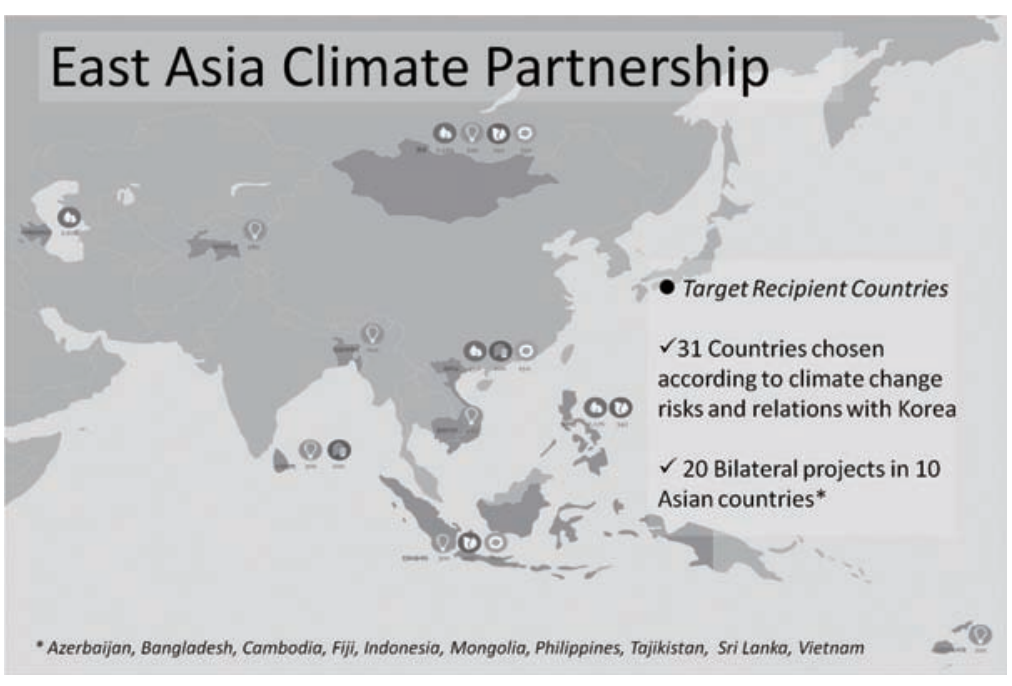

* 출처: 동아시아기후파트너십(EACP) 성과보고서 
〈물 랜드마크 사업 지원 국가〉

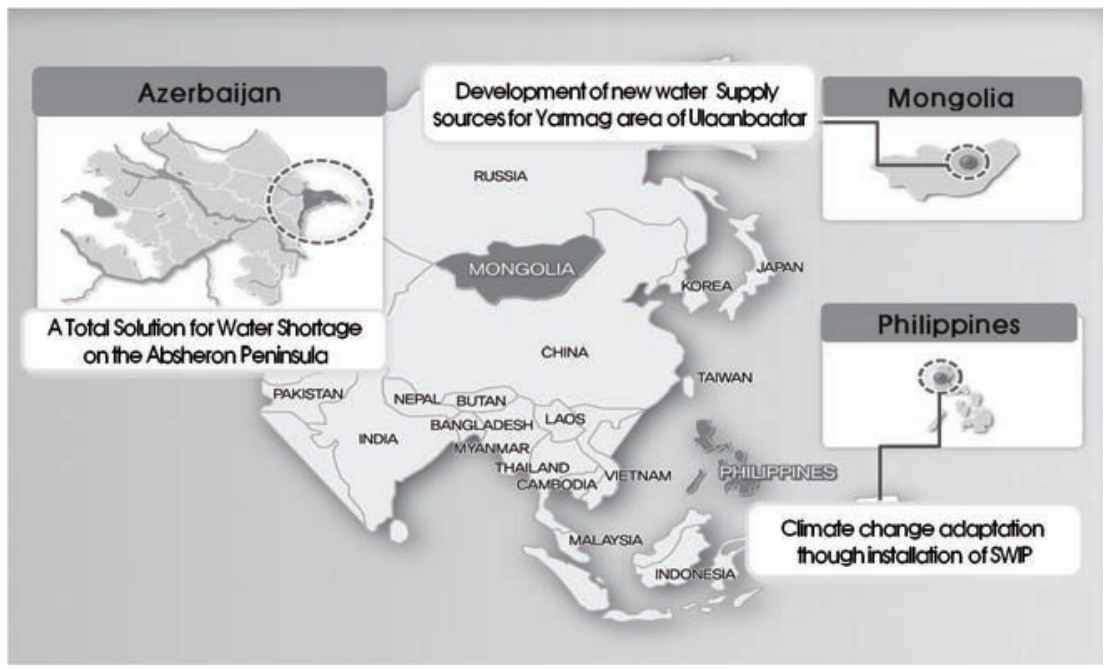

제I장

제II장

섹

터

제III장

제IV장

* 출처: 동아시아기후파트너십(EACP) 성과보고서

[1] 몽골 울란바타르시 야르막(Yarmag)지역 용수공급 및 수자원이용 효율화 사업 (2011-2013/2,260만 달러)

지속적인 수자원 부족과 유민들의 유입인한 급격한 인구증가로 인한 용수문제를 해결하는 사업으 로써 태양광 발전시설 및 소수력 에너지 시설을 구축하여 대기오염 저감 및 환경 보건 증진 효과를 가져올 수 있었다. 이는 단순 용수공급시설을 구축하는 것이 아닌 물 관리 및 개발역량을 강화하는 데도 기여하였다.

[2] 필리핀 농업용수 확보 및 홍수피해 저감을 위한 소규모 저류시설 건설사업 (2010-2015/2,167만 달러)

재난 취약국 중에 하나인 필리핀은 기후변화로 인한 홍수, 태풍, 가뭄 등의 영향으로 주요 농산물 의 수확량이 현저하게 감소되면서 식량안보에 위협을 받고 있는 상황이었다. 따라서 해당지역에 소 규모 저류시설 건설을 통해 자연재해를 감소시키고 2차적으로 확보된 수자원을 통해 농업생산성을 증대 시키는 등 농촌지역의 빈곤감소에도 기여할 수 있었다. 이는 농촌빈곤 퇴치를 연계 지원하는 차별화된 전략으로 사업효과를 극대화하는 양자협력의 사례로 소개되고 있다. 


\section{[3] 아제르바이잔 압쉐론반도지역 재생 수자원 개발 중심의 물 관련 복합사업 (2010-2013/2,618만 달러)}

기후변화에 따른 물 부족으로 사막화가 빠르게 진행되고 있던 아제르바이잔은 대표적인 국제공유 하천 인접국으로써 향후 국가간 물 분쟁 소지를 안고 있었다. 따라서 안정적인 상수공급으로 물 부 족 문제를 해결하고 주민 생활수준을 개선하는 등 농장물의 생산성 향상과 더불어 기후변화 대응 선 도국가 이미지 제고에도 기여하는 사업이 되었다.

또한, 이 사업은 국내 최대 규모의 물 분야 유무상 원조 연계형 대표사업으로 우리나라의 수자원 관리 기술의 우수성을 전달함으로써 중앙아시아 전역에 물 관리 사업 진출 교두보를 마련하는 계기 가 되었다.

\section{3. $\mathrm{KOICA}$ 의 오늘과 미래}

물 분야는 기후변화 및 인구성장, 도시화, 산업화 등 여러 요인들의 영향으로 사업타당성 예측이 어려운 분야이지만 전 세계국가들이 이에 따른 분쟁과 갈등 이면에서 물을 평화적으로 공정하게 이용 하는 노력도 동시에 이루어지고 있는 것이 사실이다(이현, 2015). 이에 발맞추어 대한민국의 유일한 무상원조기관인 한국국제협력단은 개발도상국의 경제 활성화 및 원조효과성 제고를 도모하고자 상생 의 플랫폼 역할을 확대하고, 국제사회의 논의에 적극 참여하여 글로벌 파트너십을 구축하고 있다.

또한 개도국 거버넌스 구축 및 SMART 새마을 운동 등 우리나라의 개발경험을 개도국 특성에 맞 게 맞춤형으로 지원하여 개도국의 빈곤퇴치, 국제적으로는 불평등 해소에 기여하고자 한다. 이는 곧 물의 위기를 바르게 진단하고 서로 상생하고자 하는 노력의 일환으로서 국제사회에 기여하는 한국의 노력이라고 말할 수 있다.

앞으로 $\mathrm{KOICA}$ 는 지난 과거, 지금 현재의 활동들과 마찬가지로 건강과 복지의 기반이며 경제활동 에 필수적이 요소가 되는 물의 역할과 중요성을 더욱 강조하고 전 지구적인 물의 위기를 공유하여 개 발도상국에 대한 물 분야 ODA사업 지원을 추진할 것이다. 이는 우리나라 경제력에 상응하는 ODA 규모 확대 노력과 더불어 Post-2015 목표 및 국제사회 가치에 부합하는 선진화된 물 분야 ODA사 업 수행함으로써 KOICA 활동을 통한 국민이 하는 외교를 실현할 것이다. 


\section{IV. 결론}

본 고에서 물 관련 재해와 세계의 지원 동향을 살펴보고 우리나라와 $\mathrm{KOICA}$ 의 물 분야 지원사례 를 소개하는 것을 목적으로 하였다. 2015년은 세계 재해위험경감회의, 지속가능발전을 위한 MDG 달성에서 향후 10 년을 위한 SDG 전환의 해이다. 또한 지난 4월 대한민국에서 전 세계의 물 문제를 공유하고 그 해결책을 모색해가는 회의를 개최함으로써 많은 공여국가 간 정책 선언문 및 지침서 발 간 등 물 관련 재해경감과 개발협력을 전략적으로 다루었다.

우리나라는 그동안 물 관련 재해경감을 위한 개도국 지원의 필요성에 대해 전략 단계부터 체계적 으로 추진하기보다는 제한된 분야의 단발성 사업 중심으로 개도국을 지원해 온 경향이 있다. 이는 장기적으로 계획적이고도 지속가능한 개발사업을 수행하면서 공여국과 개발도상국간의 긴밀한 협력 체계를 구축함으로 해결될 수 있을 것이다.

물 관련 분야는 기후변화, 도시화 등의 영향으로 사업타당성 예측이 특히 어려운 분야로 마스터 플랜수립과 타당성조사 단계에서 사업의 효율성을 극대화 하는 계획이 반드시 수립되어야 할 것이 다. 이를 위해서는 상대국의 요구를 정확하게 파악하고 정책 및 법 제도 등을 다각적인 시각에서 검 토하여 지속적인 수원국과의 협의 과정을 통해 물과 재해관련 정책과 연계하여 추진할 수 있어야 할 것이다.

이렇게 개발도상국에서 실현가능한 계획이 수립된 이후에는 이를 바탕으로 실질적 시범사업을 진 행하고 최종적으로 지속가능한 목표를 실현했을 때, 이 성과를 기반으로 실행모듈의 검증을 거쳐 수 원국내 전 지역, 더 나아가 기타 주변국으로 규모를 확장하고 확산할 수 있을 것이다. 바람직한 공적 원조에 부합하는 실행모듈의 완성으로 원조사업을 통한 민간과 공공기관의 협력체계를 구축하고 다 양한 개발주체가 보유한 혁신적 기술 및 아이디어를 개발협력 사업에 접목시킴으로써 개발성과를 제 고하는 전문적인 체계 마련의 기틀이 될 것이다. 또한 이를 과학적이고 계량화된 지표를 통한 $\mathrm{M \& E}$ 를 통해 효과성 제고에 이바지 할 수 있을 것이다.

마지막으로 국제사회에서 언급되고 있는 생물다양성 및 산림, 습지, 탄소순환 등의 생태계시스템 을 고려하는 원조개발을 구상해야 할 것이다. 전 지구적인 물 순환 문제의 중심은 생태계를 논의하 지 않고서는 이루어 질 수 없다. 생태계의 지속적인 건강과 물의 순환을 인식하는 것이야 말로 궁극 적으로 효율적이고 효과성 있는 경제가치 모델이며, 생태계시스템의 상호연결을 고려한 친화적인 경 제정책 및 원조사업이 이루어 질 때, 혁신적이고도 진정한 의미의 지속가능한 공적개발원조라 할 수 있을 것이다. 


\section{〈참고문헌〉}

\section{1. 국내문헌}

국제개발협력위원회. 2014. 『대한민국 ODA백서」

이현. 2015. “물분쟁과 국제개발협력”. 『개발과 이슈」. 23호. 성남: 한국국제협력단

\section{2. 국외문헌}

Alcamo, J.; Floerke, M.; Maerker, M. 2007. "Future long-term changes in global water resources driven by socio-economic and climatic changes". Hydrological Sciences Journal, 52: 247-275.

Elliot, Larr y. 2014. "Climate change will 'lead to battles for food', says head of World Bank". The Guardian. Retrieved from http://www.theguardian.co m/ environment/2014/apr/03/climate-change-battle-food-head-world-bank

Gehrig, Jason and Rogers, Mark M. 2009. Water and Conflict: Incorporating Peace building into Water Development. Baltimore: Catholic Relief Services. Retrieved from http://static1.1.sqspcdn.com/static/f/7528 98/9984899/1296501842833/waterconflict.pdf?token=PvffBdNYRBCxSMf7q MnwebDP1M0\%3D

World Bank. 2010. Annual Report. Washington D.C.: World Bank

\section{3. 참고 웹사이트}

UN World Water Day, http://www.unwater.org/water-cooperation-2013/watercooperation/facts-and-figures/en/

ODA Korea, http://www.odakorea.go.kr 